\title{
Field, Experimental, and Modeling Study of Arsenic Partitioning across a Redox Transition in a Bangladesh Aquifer
}

\author{
Hun Bok Jung, ${ }^{\dagger} \S$ Benjamin C. Bostick, ${ }^{\ddagger}$ and Yan Zheng ${ }^{*} \dagger, \ddagger$
}

${ }^{\dagger}$ School of Earth and Environmental Sciences, Queens College, and Graduate School and University Center, City University of New York, Flushing, New York 11367, United States

${ }^{\ddagger}$ Lamont-Doherty Earth Observatory, Columbia University, Palisades, New York 10964, United States

Supporting Information

ABSTRACT: To understand redox-dependent arsenic partitioning, we performed batch sorption and desorption experiments using aquifer sands subjected to chemical and mineralogical characterization. Sands collected from the redox transition zone between reducing groundwater and oxic river water at the Meghna riverbank with $\mathrm{HCl}$ extractable $\mathrm{Fe}(\mathrm{III}) / \mathrm{Fe}$ ratio ranging from 0.32 to 0.74 are representative of the redox conditions of aquifers common in nature. One brown suboxic sediment displayed a partitioning coefficient $\left(K_{\mathrm{d}}\right)$ of $7-8 \mathrm{~L} \mathrm{~kg}^{-1}$ at equilibrium with $100 \mu \mathrm{g} \mathrm{L}-1$ As(III), while two gray reducing sediments showed $K_{\mathrm{d}}$ of $1-2 \mathrm{~L} \mathrm{~kg}^{-1}$. Lactate amendment to aquifer sands containing $91 \mathrm{mg} \mathrm{kg}^{-1} \mathrm{P}$ extractable As resulted in the reduction of As and Fe with sediment Fe(III)/Fe decreasing from 0.54 to 0.44 , and mobilized an equivalent of $64 \mathrm{mg} \mathrm{kg}^{-1}$ As over a month. Desorption of As from nonlactate-amended sediment was negligible with little change in sediment $\mathrm{Fe}(\mathrm{III}) / \mathrm{Fe}$. This release of As is consistent with microbial reduction of $\mathrm{Fe}(\mathrm{III})$ oxyhydroxides and the resulting decrease in the number of surface sites on $\mathrm{Fe}(\mathrm{III})$ oxyhydroxides. Arsenic partitioning $\left(K_{\mathrm{d}}\right)$ in iron-rich, sulfur-poor aquifers with circumneutral $\mathrm{pH}$ is redox-dependent and can be estimated by $\mathrm{HCl}$ leachable sediment $\mathrm{Fe}(\mathrm{III}) / \mathrm{Fe}$ ratio with typical Fe concentrations.

\section{INTRODUCTION}

Quantification of arsenic partitioning between solute and solid phases is important to assess transport of this toxic element in aquifers. The sorption reactions of As have been extensively investigated for synthetic $\mathrm{Fe}, \mathrm{Mn}$, and $\mathrm{Al}$ oxyhydroxides and for clay minerals. ${ }^{1-4}$ A handful of studies examined natural soil or sediments under oxic conditions and found that sorption behavior was mostly similar to that of pure $\mathrm{Fe}$ (III) oxyhdyroxides. $^{5-7}$ A knowledge gap exists for As partitioning in reducing aquifers conducive to As mobilization due to difficulties in sample preservation for sorption experiments and mineralogical characterization. ${ }^{8}$

Sorption isotherms of $\mathrm{As}$ (III) onto sands from a coastal aquifer of Waquoit Bay, $\mathrm{MA}^{9}$ suggest a redox-dependent As partitioning, ${ }^{10,11}$ showing increasing As(III) sorption with higher $\mathrm{Fe}(\mathrm{III})$ oxides content. In the Ganges-BrahmaputraMeghna Delta (GBMD, South Asia), the As(III) sorption coefficient $\left(K_{\mathrm{d}}\right)$ at equilibrium with a typical groundwater As concentration of $\sim 100 \mu \mathrm{g} \mathrm{L}^{-1}$ established by batch experiment or field investigation ranged from 2 to $6 \mathrm{~L} \mathrm{~kg}^{-1}$ for Holocene reducing aquifer sediments, ${ }^{8,12,13}$ and were approximately $20-$ $30 \mathrm{~L} \mathrm{~kg}^{-1}$ for brown sediments from deeper depths. ${ }^{14-16}$ To the best of our knowledge, batch sorption studies have not evaluated As partitioning in sediments of Bangladesh Holocene shallow aquifer, frequently enriched in groundwater arsenic under reducing conditions that are typical for many aquifers with elevated As. Because transport in aquifers is thought to influence the distribution of As in aquifers, ${ }^{17}$ improved understanding of As partitioning has implications on interpretation of the source and fate of As in the $\mathrm{GBMD}^{8}$ and elsewhere.

The objectives of this study are to quantify As partitioning by batch sorption-desorption experiments using natural sediment and porewater samples with minimal disturbance of redox condition, and to understand parameters and mechanisms controlling the mobility of As in iron-rich and sulfur-poor aquifer sediment through mineralogical characterization and geochemical modeling. Along the Meghna River bank (Bangladesh) where iron- and arsenic-rich anoxic reducing groundwater interacts with oxic river water, a redox transition zone spanning a wide range of redox conditions within small spatial distances and with enrichment of sediment $\mathrm{As}^{18}$ up to hundreds or thousands of $\mathrm{mg} \mathrm{kg}^{-1}$ provides an ideal setting. The study is especially relevant to As transport in floodplain aquifers of South Asia where elevated groundwater As is

Received: September 19, 2011

Revised: November 17, 2011

Accepted: December 22, 2011

Published: December 22, 2011 


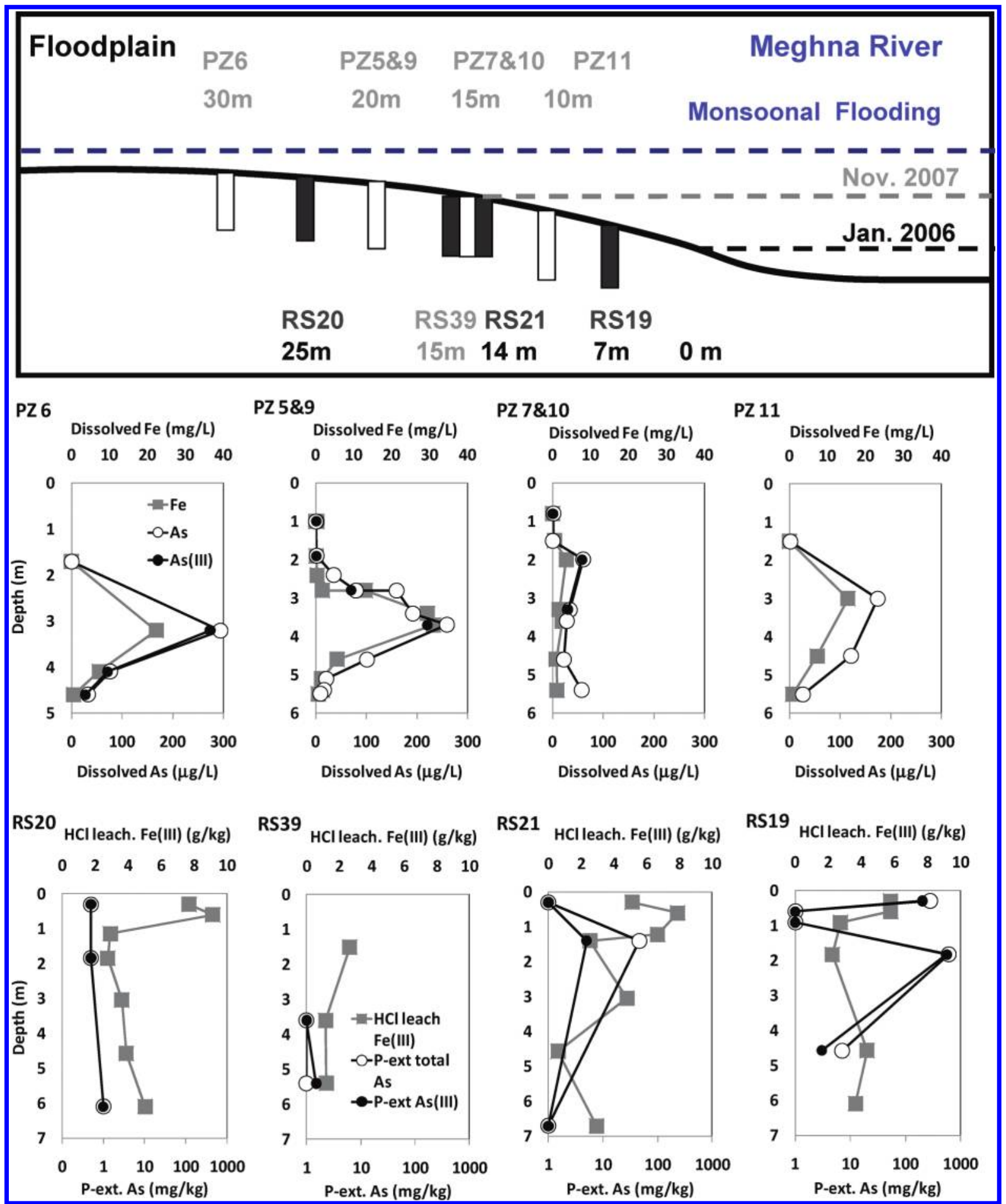

Figure 1. Top: Schematic diagram showing the location of porewater and sediment core sampling collected in Jan 2006 (black font) and Nov 2007 (gray font) with the distance from the river shore in Jan 2006. Open bars and solid bars indicate porewater piezometers and sediment cores, respectively. Middle: Depth profiles of porewater dissolved Fe, As, and As(III) concentrations. Bottom: Depth profiles of sediment HCl-leachable $\mathrm{Fe}(\mathrm{III})$ and P-extractable total As and As(III) concentrations.

widespread $^{19}$ with similar hydrogeological settings, ${ }^{20-22}$ and has implications for As transport in aquifers.

\section{MATERIALS AND METHODS}

Sediment and Porewater Samples. In addition to shallow well groundwater and river water (Table S1), sediment and porewater depth profiles (Figure 1) were collected from surface to 6-7 m depth near the Meghna River shore $\left(23.6^{\circ} \mathrm{N}\right.$,
90.6 $\mathrm{E}$ ) in Gazaria, Bangladesh (Figure S1) using a soil probe (AMS Inc., USA) and a stainless steel drive point piezometer system (Retract-A-Tip, AMS Inc.) at corresponding depths in Jan 2006 and Nov 2007. Sampling and analysis procedures are similar to those of Jung et al. ${ }^{9}$ and are described in the Supporting Information in detail. Sorbed sediment As was determined by $\mathrm{N}_{2}$-purged $1 \mathrm{M}$ sodium phosphate (Fisher) solution containing $0.1 \mathrm{M}$ ascorbic acid for $36 \mathrm{~h}$ in a crimp- 
sealed amber vial to characterize sediment samples, including the sorption-desorption experiments (Tables S2, S6, and S7). A hot $1.2 \mathrm{~N} \mathrm{HCl}$ extraction was conducted at $80{ }^{\circ} \mathrm{C}$ for $1 \mathrm{~h}$ for the same samples to determine As, Fe, Mn, S, and P associated with $\mathrm{Fe}$ oxides. For the sorption experiment, three sediment samples at depths of 1.5, 3.6, and $5.4 \mathrm{~m}$ from core RS39, paired with porewater samples (PZ10) from the same depth interval, were collected on Nov 4, 2007. For the desorption experiment, a section of RS19-4 (depth 1.5-1.8 m) collected on Jan 25, 2006 was used. Sediment cores were double-sealed in nitrogenfilled Mylar bags with oxygen absorbent (SorbentSystems) during transportation, and refrigerated at $4{ }^{\circ} \mathrm{C}$ prior to use.

X-ray Absorption Spectroscopy. The arsenic speciation and $\mathrm{Fe}$ mineralogy were analyzed by X-ray absorption spectroscopy (XAS) at the Stanford Synchrotron Radiation Laboratory. Iron mineralogy was obtained using extended X-ray absorption fine structure (EXAFS) spectroscopy. Arsenic speciation was determined using X-ray absorption near edge spectroscopy (XANES). Due to the very similar spectra between less crystalline goethite and ferrihydrite, which may be hard to differentiate based on linear combination fitting approaches, ${ }^{23}$ the concentrations of ferrihydrite estimated represent the sum of ferrihydrite and freshly precipitated (poorly crystalline) goethite (Supporting Information).

Batch Sorption Experiment. One suboxic brown sediment with $\mathrm{Fe}(\mathrm{III}) / \mathrm{Fe}$ of 0.58 and two reducing gray sediments with $\mathrm{Fe}(\mathrm{III}) / \mathrm{Fe}$ ratio of $\sim 0.37$ from $\mathrm{RS} 39$, containing $\mathrm{HCl}$ leachable or P-extractable As of $\sim 1 \mathrm{mg} \mathrm{kg}^{-1}$ (Table S2; HCland P-extraction were conducted using different aliquots of the same sample), were subjected to batch sorption experiment in the field in a $\mathrm{N}_{2}$ filled glovebox immediately after sample collection. About $10 \mathrm{~mL}$ of porewater $(\mathrm{pH} 6.0-6.5)$ from the same depth (PZ10, Table S3) was added to $15-\mathrm{mL}$ amber serum vials containing 5-6 g of homogenized sediment spiked with $\mathrm{As}(\mathrm{III})$ and $\mathrm{As}(\mathrm{V})$ stock solutions freshly prepared using reagent grade $\mathrm{NaAsO}_{2}$ and $\mathrm{NaHAsO}_{4} \cdot 7 \mathrm{H}_{2} \mathrm{O}$ to yield concentrations from 0 to $\sim 7000 \mu \mathrm{g} \mathrm{L}^{-1}$ As (Table S4). The vials were crimp-sealed without headspace and intermittently shaken, kept in a $\mathrm{N}_{2}$-filled chamber except during transportation in $\mathrm{N}_{2}$-filled Mylar bags, and sampled after 7 days. The supernatant was analyzed for As(III) immediately by voltammetry after filtration through a $0.45-\mu \mathrm{m}$ membrane filter and acidification to $1 \% \mathrm{HCl}$ and for total As by ICP-MS (Supporting Information). The $\mathrm{pH}$ of the supernatant likely remained circumneutral during the experiment because sediment and porewater samples were from the same depth, and thus were already at equilibrium.

Batch Desorption Experiment. To ascertain the mobility of As found at high concentrations $\left(46-600 \mathrm{mg} \mathrm{kg}^{-1} \mathrm{P}\right.$ extractable As), a sediment core section (1.5-1.8 $\mathrm{m}$ depth) from RS19-4 was homogenized inside a $\mathrm{N}_{2}$-filled chamber, and reacted with suboxic nanopure water $(>18 \mathrm{M} \Omega)$ or artificial groundwater for 1 month. Artificial groundwater and nanopure water were purged with pure nitrogen gas to reach a dissolved oxygen value of $\sim 0.5 \mathrm{mg} \mathrm{L} \mathrm{L}^{-1}$, determined by a CHEMets dissolved oxygen kit. The homogenized sample contained a Pextractable As concentration of $91 \mathrm{mg} \mathrm{kg}^{-1}$ with $57 \mathrm{mg} \mathrm{kg}^{-1}$ as As(III), HCl-leachable Fe and As concentration of 6933 and 86 $\mathrm{mg} \mathrm{kg}^{-1}$, respectively. Artificial groundwater composition was based on that of the typical groundwater composition from adjacent tube wells at similar depths: $1 \mathrm{mM} \mathrm{NaHCO} 3,0.02 \mathrm{mM}$

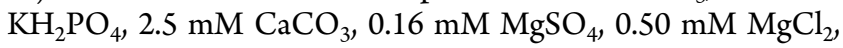

and $0.06 \mathrm{mM} \mathrm{KCl}$, and was buffered to a $\mathrm{pH}$ of 6.8 using 20 mM PIPES (piperazine- $N, N^{\prime}$-bis(2-ethanesulfonic acid)).

There were four types of amendment. Type I used nanopure water $(\mathrm{pH}=6.0)$ with $50 \mathrm{mg} \mathrm{L}^{-1}$ kanamycin, an antibiotic. Type II used artificial groundwater $(\mathrm{pH}=6.8)$ with $50 \mathrm{mg} \mathrm{L}^{-1}$ kanamycin. Type III is the same as Type II but without kanamycin, serving as a biotic control. Type IV is Type III plus $1 \mathrm{mM}$ lactate, serving as an enhanced biotic control. Kanamycin was intended to limit indigenous microbial activities. Each series started in 5 replicates of $15-\mathrm{mL}$ serum bottles containing $5 \mathrm{~mL}$ of nanopure water or artificial groundwater and $\sim 1 \mathrm{~g}$ of sediment. All glassware was autoclaved. After flushing the headspace with $\mathrm{N}_{2}$ gas and crimp sealing, bottles were shaken at 140 rpm over 1 month in a $\mathrm{N}_{2}$ filled anaerobic chamber (Coy Laboratory Products) without $\mathrm{H}_{2}$ but with oxygen absorbent (SorbentSystems). The supernatant and sediment for 4 types of incubation were sampled sacrificially from a replicate of each type on the 2nd, 5th, 10th, 17th, and 30th day. Total Fe, Mn, S, $\mathrm{P}$, and As in filtered supernatant and sediment extracts by hot $\mathrm{HCl}$ and anoxic sodium phosphate were analyzed, as well as $\mathrm{Fe}(\mathrm{II})$ and As(III) (Supporting Information).

Langmuir Isotherm and Surface Complexation Modeling (SCM). Batch sorption equilibrium data were fitted to Langmuir isotherms to determine sorption capacity $\left(S_{\max }\right)$ and $K_{\mathrm{La}}$ a constant representing the binding strength, and the effective $K_{\mathrm{d}}$ values at equilibrium with $100 \mu \mathrm{g} \mathrm{L}^{-1}$ As, typical of Bangladesh groundwater. ${ }^{8}$ A semimechanistic SCM of sorption experimental data was conducted in PHREEQC version 2.15 with MINTEQA2 version 4.0 database, using the acidity constants and equilibrium constants $(K$; Table S5) for a diffuse double-layer surface complexation model of hydrous ferric oxide (HFO), ${ }^{24}$ given that $\mathrm{Fe}(\mathrm{III})$ oxyhydroxides are the dominant reactive mineral phase in suboxic sediment (Table 1). Other Fe phases and primary minerals such as quartz, feldspar, and mica vary little along the depth profiles, ${ }^{18}$ and are not included. For both amorphous and crystalline $\mathrm{Fe}$ (III) oxide minerals, the same sorption equilibrium constants were applied because intrinsic surface complexation constants of metals and anions for both HFO and goethite have been found to be similar. $^{25}$ Surface complexation of $\mathrm{Si}$ was not considered because the $K$ value is not available from MINTEQA2 database. Surface site density was adjusted based on $\mathrm{HCl}$ leachable $\mathrm{Fe}$ (III) concentrations, assuming that $\mathrm{Fe}$ minerals are goethitelike phases with $\sim 0.01 \mathrm{~mol}$ surface sites per mol Fe(III) ${ }^{26}$ to fit As data in sorption SCM modeling. Based on the composition of porewater (Table $\mathrm{S} 3$ ), $\mathrm{pH}, \mathrm{Ca}$, and alkalinity were fixed to 6.0, $0.3 \mathrm{mM}$, and $0.6 \mathrm{mM}$ for brown sediment, respectively, and were $6.3,1 \mathrm{mM}$, and $2 \mathrm{mM}$ for gray sediment, respectively. $\mathrm{P}$ concentrations of 0.005 and $0.04 \mathrm{mM}$ were used for brown and gray sediments, respectively, according to aqueous composition at the end of the experiment. In desorption SCM modeling for type III without lactate and type IV with lactate, all Pextractable As of $91 \mathrm{mg} \mathrm{kg}^{-1}$ was subjected to adsorption reactions. For each sampling time point, solid-phase arsenic redox speciation was considered for modeling. Based on Pextractable sediment As data, the percentage of As(III) was initially $50 \%$, decreasing to $40 \%$ on day 17 , and $30 \%$ on day 30 in type III. In type IV, the percentage of As(III) was initially $50 \%$, increasing to $60 \%$ on day $2,70 \%$ on day $5,80 \%$ on day 10 , and $100 \%$ on days 17 and 30 . The surface site density was estimated using $\mathrm{HCl}$ leachable $\mathrm{Fe}(\mathrm{III})$ concentration for each sampling point. For type III, Fe minerals were presumed to be like ferrihydrite with $0.20 \mathrm{~mol}$ surface sites per mol Fe(III $)^{24}$ 


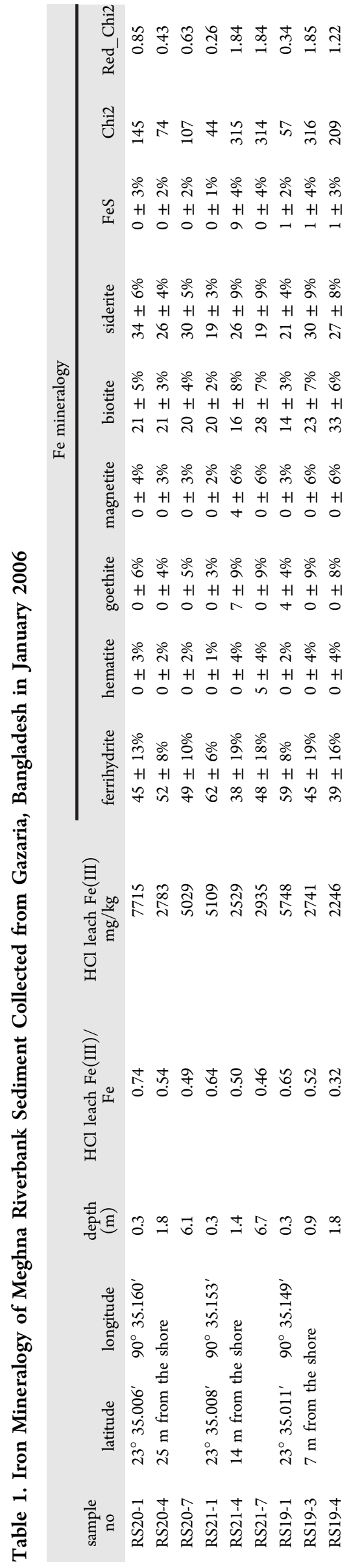

during a period of 1 month, whereas for type IV, it was assumed that $\mathrm{Fe}$ minerals were initially ferrihydrite-like $\mathrm{Fe}(\mathrm{III})$ mineral with $0.20 \mathrm{~mol}$ surface sites per mol $\mathrm{Fe}(\mathrm{III})$, and finally transformed to magnetite-like Fe(II, III) minerals with $\sim 0.01$ mol surface sites per mol Fe(III). Based on aqueous data, $\mathrm{pH}$, $\mathrm{Ca}$, alkalinity, and $\mathrm{P}$ were fixed to $6.8,2.5,5$, and $0.01 \mathrm{mM}$, respectively.

\section{RESULTS AND DISCUSSION}

Redox Transition Zone. A redox transition zone between approximately 0 and $2 \mathrm{~m}$ depth is evident from depth profiles of porewater and sediment Fe and As (Figure 1). Porewater Fe and As reach peak concentrations of $20-30 \mathrm{mg} \mathrm{L}^{-1}$ and $200-$ $300 \mu \mathrm{g} \mathrm{L}^{-1}$ between 3 and $4 \mathrm{~m}$ although PZ7 and 10 depth profiles show a less pronounced peak most likely due to deeper infiltration of oxic river water at the shore (Figure 1). Dissolved As speciation is dominated by As(III) $(90 \pm 5 \% ; n=7)$ at depth $\geq 2$ m but has less As(III) $(57 \pm 7 \% ; n=3)$ at depth $<2$ $\mathrm{m}$. HCl-leachable sediment Fe(III) was highest at depths $<1 \mathrm{~m}$ $\left(6.3 \pm 2.7 \mathrm{~g} \mathrm{~kg}^{-1}, n=7\right)$ and decreased rapidly with depth (3.3 $\pm 1.7 \mathrm{~g} \mathrm{~kg}^{-1}$ at depth of $1-2 \mathrm{~m}, n=6 ; 3.1 \pm 1.5 \mathrm{~g} \mathrm{~kg}^{-1}$ at depth $>2 \mathrm{~m}, n=10)$. This decrease correlates to decreases in the $\mathrm{Fe}(\mathrm{III}) / \mathrm{Fe}$ ratio $(0.65 \pm 0.07$ at depth $<1 \mathrm{~m}, 0.53 \pm 0.12$ at depth of $1-2 \mathrm{~m}$, and $0.40 \pm 0.11$ at depth $>2 \mathrm{~m})$. This redox transition zone develops because the river water level declines faster than the groundwater table after the monsoon season (April-October) and causes a hydraulic gradient from the aquifer toward the river, ${ }^{8}$ driving discharge of anoxic groundwater $\left(\mathrm{DO}<\sim 0.1 \mathrm{mg} \mathrm{L}^{-1}\right)$ to oxic river water $(\mathrm{DO}>5 \mathrm{mg}$ $\left.\mathrm{L}^{-1}\right)$. A summary of the average chemical composition of groundwater, porewater, and river water is available in Supporting Information (Table S1).

Iron Mineralogy and Sediment Arsenic. In most cases, the dominant $\mathrm{Fe}$ mineral in 9 samples analyzed was ferrihydrite-like, accounting for $49 \pm 8 \%$ of $\mathrm{Fe}$ minerals at depths $<2 \mathrm{~m}$ (Table 1, Figure S2). Small concentrations of crystalline goethite and hematite were also detected in 2 samples (Table 1), and these concentrations probably represent minimum values given that microcrystalline $\mathrm{Fe}(\mathrm{III})$ oxides have spectra that are similar to ferrihydrite and thus may in some cases not be quantified separately. The preponderance of ferrihydrite is somewhat surprising because it commonly converts to more stable oxides. ${ }^{27,28}$ We explain this apparent discrepancy as follows. First, ferrihydrite commonly forms through the rapid oxidation of $\mathrm{Fe}(\mathrm{II})$ at neutral $\mathrm{pH},{ }^{27}$ and the study site is characterized by the active discharge of $\mathrm{Fe}$ (II)-rich groundwater. Second, coprecipitated silica, organic matter, and trace metals from groundwater may stabilize the ferrihydrite. ${ }^{29}$ Kinetics of seasonal transformation of ferrihydrite to stable $\mathrm{Fe}$ phases is likely affected by the seasonal transition of hydrological condition between dry season and rainy season. The prevalence of $\mathrm{Fe}$ (III) minerals at shallow depths and then decreasing with depth is consistent with the chemical extraction data (Figure 1, Table 1). A high quantity of Fe(II) minerals (26 $\pm 5 \%$; fit as siderite), as well as iron silicates ( $22 \pm 6 \%$; fit as biotite), are also present in the samples. The presence of biotite or other Fe silicates indicates that sediments are young because it weathers rapidly to secondary Fe(III) oxides. Although green rust may possibly be present in Bangladesh aquifer, ${ }^{8}$ green rust was not considered due to its metastable nature. ${ }^{27}$

P-extractable sediment As concentration is elevated between 0 and $2 \mathrm{~m}$ depth and within $\sim 15 \mathrm{~m}$ distance from the river, showing $46 \mathrm{mg} \mathrm{kg}^{-1}$ As at RS21, 284, and $600 \mathrm{mg} \mathrm{kg}^{-1}$ As at 
RS19 (Figure 1). XRF analyses of another sediment core (RS34) collected $2 \mathrm{~m}$ away from the shore found that bulk sediment As concentration is $100 \mathrm{mg} \mathrm{kg}^{-1}$ at $1.4 \mathrm{~m}$ depth. Sediment As speciation determined by P-extraction and XANES (Figure 1, Figure S2, Table S6) suggests mixed As(III) and As(V) (Supporting Information).

Langmuir Sorption Isotherms. As(III) sorption to sediment core RS39 was equilibrated within $10 \mathrm{~h}$. Adsorption data fit well to Langmuir isotherms (Figure 2; RMSE $\leq 0.6$ )

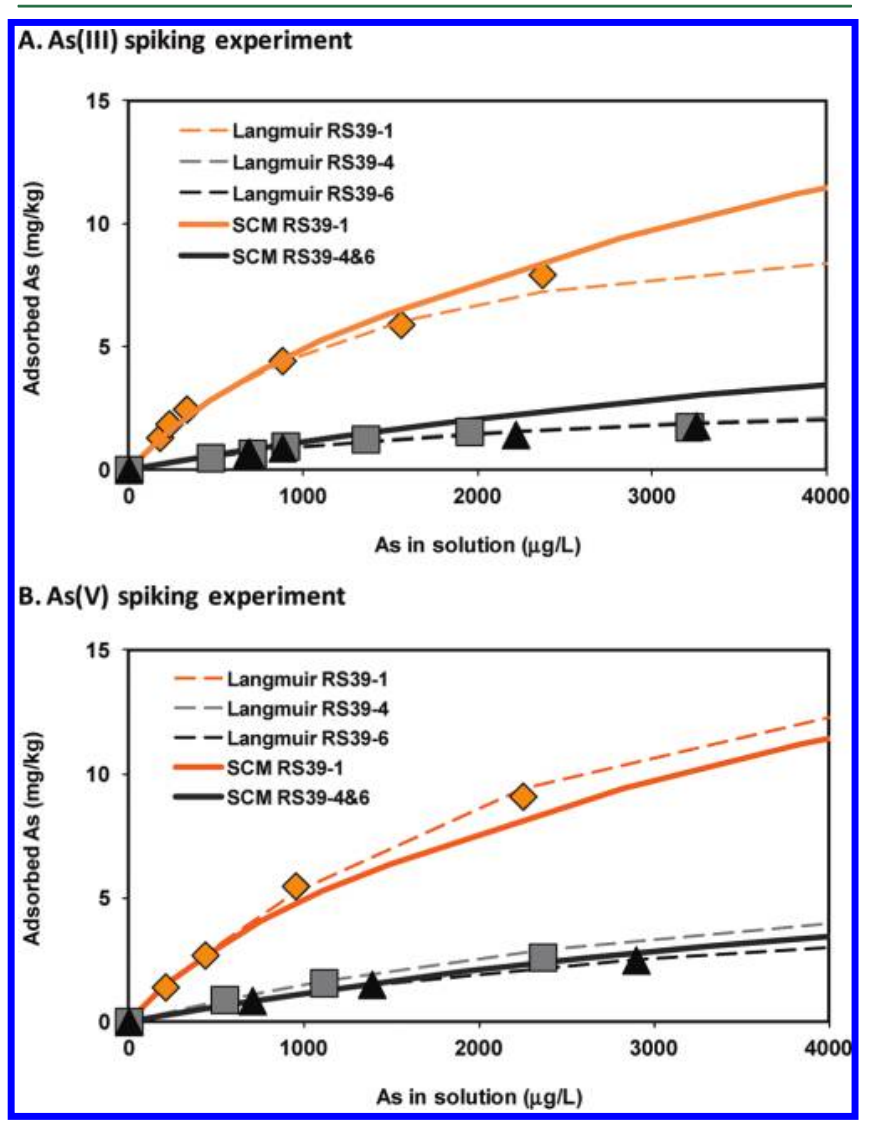

Figure 2. Equilibrium isotherms of As sorption to one brown (diamond) and two gray sediment (triangle and square) samples (RS39) collected in Nov 2007. (A) As(III) spiking experiment; (B) As $(\mathrm{V})$ spiking experiment. Dashed lines represent Langmuir isotherm fit. Solid lines represent surface complexation model fit and sorbed As species is $100 \%$ As(III) in SCM.

that differ considerably depending on the color (redox state) of the sediment. Based on these isotherms, the calculated $K_{\mathrm{d}}$ values at equilibrium with $100 \mu \mathrm{g} \mathrm{L}^{-1}$ solute As are 7-8 and 1$2 \mathrm{~L} \mathrm{~kg}^{-1}$ for brown and gray sediments, respectively (Table S2). These values are comparable regardless of whether sediments were spiked with As(III) or As(V). For gray sediment, as solute As increases from 10 to $1000 \mu \mathrm{g} \mathrm{L}^{-1}$, a typical groundwater As concentration range in the GBMD aquifers, the $K_{\mathrm{d}}$ value of the gray sediment is nearly constant at $1-2 \mathrm{~L} \mathrm{~kg}^{-1}$, similar to a relatively constant $K_{\mathrm{d}}$ of $\sim 4 \mathrm{~L} \mathrm{~kg}^{-1}$ that was proposed for reducing shallow aquifer of GBMD across a range of As concentrations of nearly 3 orders of magnitude. ${ }^{13}$

The sorption capacity $\left(S_{\max }\right)$ for brown sediment was also about 2-3 times higher than that for gray sediment (Table S2). Regardless of whether As(III) or As(V) was spiked, the dissolved As was primarily As(III) ( $94 \pm 11 \%$ and $89 \pm 14 \%$ for As(III) and As(V) additions, respectively, Table S4) possibly due to redox processes readily reducing $A s(V)$ to As(III). This may in part explain the similar sorption behaviors in As(III) and $\mathrm{As}(\mathrm{V})$ spiked experiments because it is essentially As(III) equilibrium (Figure 2).

Surface Complexation Model. For As(III) and As(V) spikes, the best-fitted surface site density was 0.6 and $0.2 \mu \mathrm{M}$ $\mathrm{g}^{-1}$ for brown and gray sediments, respectively (RMSE $<0.8$ ), assuming that all sorbed As is As(III) in SCM (Figure 2). The 3 -fold higher surface site density in brown sediment than gray sediment indicates that they have different concentrations of similar assemblage of minerals controlling adsorption. This is supported by differences in the concentration of HCl-leachable Fe(III) (Table S2), with $\sim 0.01 \mathrm{~mol}$ surface sites per mol $\mathrm{Fe}(\mathrm{III})$, assuming that $\mathrm{Fe}(\mathrm{III})$ phases are principally responsible for As retention. Using a surface site density of 3.5 sites $\mathrm{nm}^{-2}$, 30 an $\mathrm{Fe}$ mineral surface area of $\sim 20 \mathrm{~m}^{2} \mathrm{~g}^{-1}$ yields $\mathrm{Fe}$ concentrations that are consistent with observed HCl-leachable Fe(III) concentrations of $\sim 2700$ and $\sim 1200 \mathrm{mg} \mathrm{kg}^{-1}$ for brown and gray sediments, respectively (Table S2). This surface area is consistent with a range of microcrystalline $\mathrm{Fe}$ oxides such as goethite but is much lower than what is common for ferrihydrite, which was identified by XAS spectroscopy. This difference can be explained in three ways. First, it is possible or even likely that microcrystalline goethite present in these sediments anomalously fit with ferrihydrite due to spectral similarities. Second, ferrihydrite, which often has measured surface areas in excess of $200 \mathrm{~m}^{2} \mathrm{~g}^{-1,26}$ may form aggregates or have blocked surfaces that make them less reactive. Indeed, the mole ratio of As effectively scavenged by fresh ferrihydrite is about $1: 50,{ }^{31}$ consistent with a surface area of about $\sim 60 \mathrm{~m}^{2}$ $\mathrm{g}^{-1}$, and more aged forms could be less reactive. Third, the XAS data were collected in the middle of the dry season (January) during groundwater discharge. Fresh precipitates formed in such environments could indeed contain ferrihydrite that could be converted to more stable forms, catalyzed by their partial reduction ${ }^{28}$ during the following rainy season. Other sediments collected in this area have also exhibited widely different sorption capacities, possibly due to different $\mathrm{Fe}$ mineral composition. ${ }^{4}$ The As sorption capacity of $13-23 \mathrm{mg} \mathrm{kg}^{-1}$ established by the batch sorption experiment using suboxic brown sediment collected in Nov 2007 is considerably lower than that observed for suboxic sediment collected in Jan $2003^{18}$ or Jan 2006 (Figure 1), which had P-extractable sediment As concentrations as high as $100-1000 \mathrm{mg} \mathrm{kg}^{-1}$; this difference is also attributed to the seasonal transformation of $\mathrm{Fe}$ minerals. The extent of such seasonal transformations needs to be assessed in the future.

Desorption of Arsenic and Iron Mineralogy. Desorption experiments performed in the absence of lactate (types I, II, and III) released measurable As into solution within 2 days, its concentration reaching $604 \pm 57 \mu \mathrm{g} \mathrm{L}^{-1}$, primarily as As(III) (Figure 3, Table S7). This As release was decoupled from a rise of Fe concentration, with $1237,<10$, and $18 \mu \mathrm{g} \mathrm{L}^{-1}$ for types I, II, and III, respectively. Over the next 28 days, dissolved As concentrations decreased by $15-31 \%$ and it was oxidized to nearly $100 \%$ As $(\mathrm{V})$ (Table S7). The oxidation of As is also observed in the sediment, with P-extractable As(III) decreasing from $57 \mathrm{mg} \mathrm{kg}^{-1}$ to finally 15,32 , and $22 \mathrm{mg} \mathrm{kg}^{-1}$ for types I, II, and III, respectively, while the total pool of adsorbed As remained constant, with the nearly unchanged total Pextractable $(80-90 \mathrm{mg} / \mathrm{kg}$ ) and $\mathrm{HCl}$ leachable As ( 70 mg/ $\mathrm{kg}$ ) concentrations (Figure 3B, Table S7). Although we are unsure of the responsible oxidants, limited introduction of 

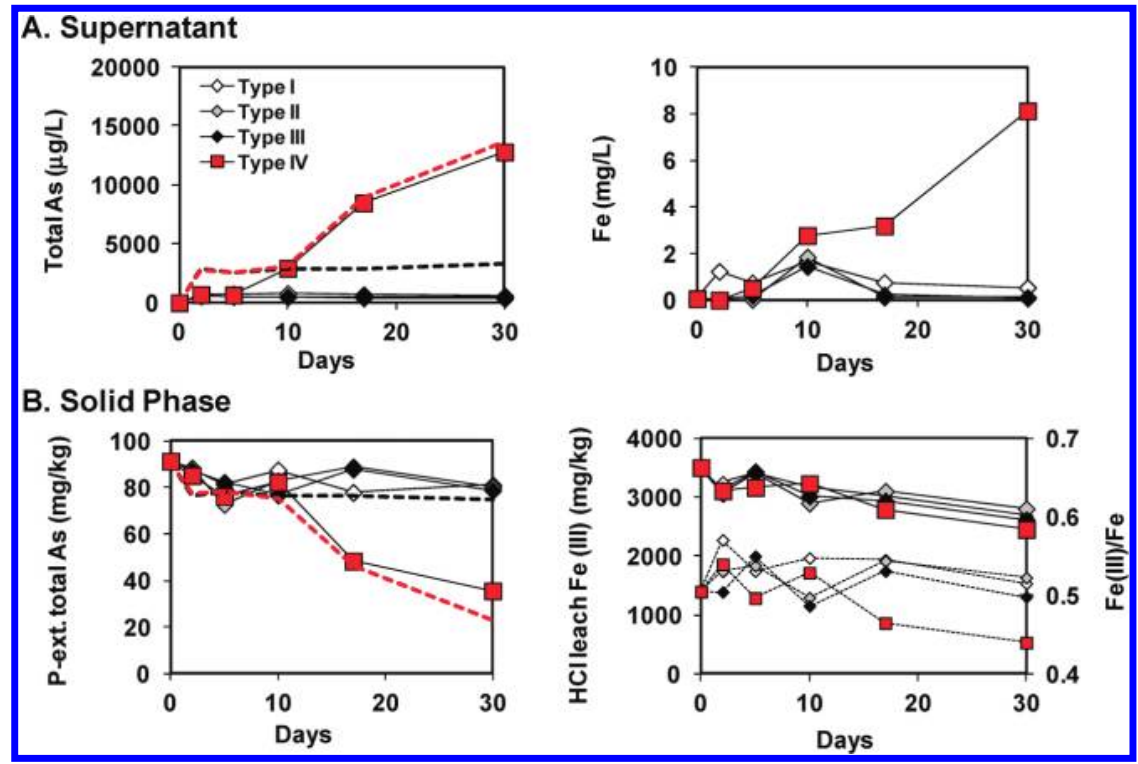

Figure 3. Fe and As in aqueous phase (A) and solid phase (B) during desorption experiment using RS19-4 sediment core collected in Jan 2006. Type I: nanopure water + kanamycin $(50 \mathrm{mg} / \mathrm{L})$; Type II: artificial groundwater + kanamycin $(50 \mathrm{mg} / \mathrm{L})$; Type III: artificial groundwater; Type IV: artificial groundwater + lactate $(1 \mathrm{mM})$. In the panel showing $\mathrm{HCl}$-leachable $\mathrm{Fe}$ (B right), solid lines with large symbols represent $\mathrm{Fe}(\mathrm{III})$ concentration, and dotted lines with small symbols are Fe(III)/Fe ratio. Surface complexation modeling of As desorption in type III without lactate and type IV with lactate are indicated by black dashed line and red dashed line, respectively.

oxygen $\left(\sim 0.5 \mathrm{mg} \mathrm{L}^{-1}\right.$ dissolved $\left.\mathrm{O}_{2}\right)$ at the beginning of the experiment, or another oxidant such as $\mathrm{Mn}(\mathrm{IV})$ oxides in the sediments, are possibilities. ${ }^{14}$ The $\mathrm{HCl}$ leachable $\mathrm{Mn}$ concentration is $\sim 100 \mathrm{mg} \mathrm{kg}$, but the mineralogy of $\mathrm{Mn}$ phase has not been confirmed in these sediments (Table S7). The overall oxidation state of sediment $\mathrm{Fe}$ was constant as evidenced by a constant $\mathrm{Fe}(\mathrm{III}) / \mathrm{Fe}$ ratio throughout the experiment $(0.5-0.55)$, while the $\mathrm{HCl}$ leachable $\mathrm{Fe}(\mathrm{III})$ decreased from its initial concentration of 3500 to $\sim 2700 \mathrm{mg}$ $\mathrm{kg}^{-1}$ over the course of the experiment (Figure 3B). This could take place when some of the $\mathrm{Fe}$ (III) oxyhydroxides are transformed to more crystalline $\mathrm{Fe}$ (III) phases (e.g., goethite, hematite), resulting in the decreased leachability by $\mathrm{HCl}$ with little change in overall oxidation state.

Sediments incubated with $1 \mathrm{mM}$ lactate (type IV) released similar quantities of As into solution $\left(\sim 630 \mu \mathrm{g} \mathrm{L}^{-1}\right.$, Figure $\left.3 \mathrm{~A}\right)$ on the second day and also without $\mathrm{Fe}\left(<10 \mu \mathrm{g} \mathrm{L}^{-1}\right)$, but As release was much more appreciable between the 5 th and the 30th day, at which point the dissolved As reached $12081 \mu \mathrm{g}$ $\mathrm{L}^{-1}$. This high As concentration is equivalent to mobilization of $64 \mathrm{mg} \mathrm{kg}^{-1}$ sediment As, or 70\% of the initial P-extractable As. Concurrent decreases in P-extractable and $\mathrm{HCl}$-leachable As concentrations were also observed, as was the nearly complete conversion of dissolved As to As(III) (Figure 3B, Table S7). The release of dissolved Fe resembled that of As except for the 17th day. In the first 5 days, Fe release was low and comparable to type I, with $482 \mu \mathrm{g} \mathrm{L}^{-1}$ dissolved $\mathrm{Fe}$, equivalent to $2.5 \mathrm{mg}$ $\mathrm{kg}^{-1}$ sediment $\mathrm{Fe}$. It then increased to $3 \mathrm{mg} \mathrm{L}^{-1}$, and finally to 8 $\mathrm{mg} \mathrm{L} \mathrm{L}^{-1}$, equivalent to $40 \mathrm{mg} \mathrm{kg}^{-1}$ sediment $\mathrm{Fe}$. The $\mathrm{HCl}-$ leachable Fe(III) decreased from 3500 to $\sim 2450 \mathrm{mg} \mathrm{kg}^{-1}$ and sediment $\mathrm{Fe}(\mathrm{III}) / \mathrm{Fe}$ ratio displayed a measurable and consistent decrease from 0.54 to 0.44 between the 10th and the 30th day (Figure 3). The change in extractable $\mathrm{Fe}(\mathrm{III}) / \mathrm{Fe}$ in the solid phase indicates that a significant portion of the $\mathrm{Fe}$ (III) was reduced (and not just changes in leachability by $\mathrm{HCl}$ ), and that much of the $\mathrm{Fe}(\mathrm{II})$ produced was conserved in the solid phase. The reduction of $\mathrm{Fe}$ and As in both solution and sediment, as well as subsequent desorption of As, appear to have been caused by microbial activity ${ }^{32}$ stimulated with addition of labile organic carbon to sediment preserved at $4{ }^{\circ} \mathrm{C}$ for 11 months. ${ }^{15}$ This is different from the naturally occurring reduction of As during sorption experiment without addition of labile organic carbon perhaps because the sorption experiment was conducted using fresh sediment containing active microbial community immediately after sample collection.

Decrease in surface site density due to microbial transformation of $\mathrm{Fe}$ minerals stimulated by lactate was likely a major cause for extensive As desorption. Although no XAS data were available to ascertain the nature of iron mineralogy change during the desorption experiment, SCM modeling based on surface sites derived from $\mathrm{HCl}$-leachable $\mathrm{Fe}(\mathrm{III})$ concentration simulated the evolution of solute (Figure $3 \mathrm{~A}$ ) and solid As (Figure 3B) reasonably well, although dissolved As is overestimated (Figure 3A). The overestimation may be due to surface site density of natural $\mathrm{Fe}$ (III) oxyhydroxides in sediment being higher than that of typical synthetic ferrihydrite ( 0.2 mol surface sites per mol Fe), or some As coprecipitated with $\mathrm{Fe}$ in sediment could not be mobilized during the experiment. The sediment $\mathrm{Fe}(\mathrm{III}) / \mathrm{Fe}$ decrease with lactate over 1 month was interpreted as a redox transformation of $\mathrm{Fe}$ minerals from an initially ferrihydrite-like $\mathrm{Fe}$ (III) mineral with $0.20 \mathrm{~mol}$ surface sites per mol $\mathrm{Fe}$ (III) to finally magnetite-like $\mathrm{Fe}(\mathrm{II}, \mathrm{III})$ minerals with $0.01 \mathrm{~mol}$ surface sites per mol Fe(III) (same as the surface site concentration from sorption experiment with RS39 sediments collected in Nov 2007), while the surface site concentrations for day 5, 10, and 17 were adjusted to $0.20,0.15$, and $0.04 \mathrm{~mol}$ per mol $\mathrm{Fe}(\mathrm{III})$, respectively, for the best fit. For types without lactate, 0.20 mol surface sites per mol $\mathrm{Fe}$ (III) were used throughout. It is worth noting that color change of Bangladesh Holocene aquifer sediment from brown to gray corresponds to a threshold $\mathrm{Fe}(\mathrm{III}) / \mathrm{Fe}$ ratio of $\sim 0.6^{33}$ Therefore, the SCM modeling results suggest that ferrihydrite-like $\mathrm{Fe}$ (III) mineral or poorly crystalline goethite with higher surface site density is initially 
the dominant Fe mineral in RS19 sediment collected in Jan 2006 and is supported by XAS data (Table 1), whereas microcrystalline goethite with lower surface site density is possibly dominant in RS39 sediment collected in Nov 2007. The results also suggest that Meghna Riverbank sediment As will remain reasonably immobile in the absence of labile organic carbon.

Redox-Dependent As Partitioning in Iron-Dominant System. Arsenic partitioning to aquifer sands appears to vary systematically with sediment redox state. The $K_{\mathrm{d}}$ values for As(III) at equilibrium with $100 \mu \mathrm{g} \mathrm{L}^{-1} \mathrm{As}(\mathrm{III})$ observed in batch sorption experiments using sands from the redox transition zones of Meghna Riverbank in this study compare favorably with those determined within the Waquoit Bay aquifer, ${ }^{9}$ as well as Bangladesh Pleistocene orange sands. ${ }^{14,15}$ Arsenic adsorption is considerably greater in orange sands than gray sands. Interestingly, adsorption (as indicated by the effective $K_{\mathrm{d}}$ ) is not clearly proportional to sediment $\mathrm{Fe}(\mathrm{III})$ concentration (Figure S4) probably due to mineralogical differences such as crystallinity and morphology, which affect the leachability of $\mathrm{Fe}$ minerals by $\mathrm{HCl}$. Instead, the $K_{\mathrm{d}}$ and sediment $\mathrm{Fe}(\mathrm{III}) / \mathrm{Fe}$ ratio can be fitted with an exponential function $\left(R^{2}=0.97, n=7\right.$; Figure 4$)$ excluding a black reducing

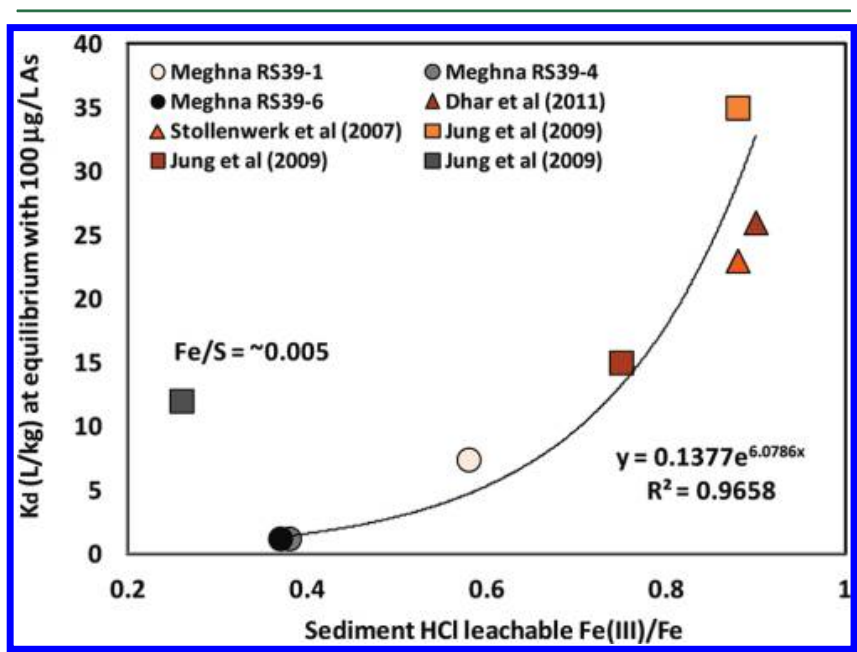

Figure 4. Correlation between $\mathrm{HCl}$-leachable $\mathrm{Fe}(\mathrm{III}) / \mathrm{Fe}$ ratio and $\mathrm{As}$ partitioning coefficient $\left(K_{\mathrm{d}}\right)$ for a solute As of $100 \mu \mathrm{g} \mathrm{L} \mathrm{L}^{-1}$ at circumneutral $\mathrm{pH}$. Data are from the Meghna riverbank (this study) and the Waquoit Bay coastal aquifer, ${ }^{9}$ and Pleistocene aquifer sands from Bangladesh. ${ }^{14,15}$ Langmuir isotherm fit was used to obtain $K_{\mathrm{d}}$, except for Stollenwerk et al., ${ }^{14}$ in which $K_{\mathrm{d}}$ was estimated based on SCM fit. The exponential fit excludes the $K_{\mathrm{d}}$ for a black Waquoit Bay sediment with porewater molar $\mathrm{Fe} / \mathrm{S}$ of $\sim 0.005$ ( $\mathrm{Fe} / \mathrm{S}<1$, a sulfurrich system). In Bangladesh aquifer, the $\mathrm{Fe}(\mathrm{III}) / \mathrm{Fe}$ ratio and $K_{\mathrm{d}}$ range from 0.37 to 0.90 and from 1 to $26 \mathrm{~L} \mathrm{~kg}^{-1}$, respectively.

sediment from Waquoit Bay with $\mathrm{Fe}(\mathrm{III}) / \mathrm{Fe}$ of $0.26 .^{9}$ The higher than expected $K_{\mathrm{d}}$ value of the black sediment from Waquoit Bay is attributed to As-sulfide precipitation ${ }^{11}$ during sorption experiment because of high sulfur and low iron concentration in porewater $\left(\mathrm{Fe} / \mathrm{S}\right.$ molar ratio <1). ${ }^{9,11,34}$ This relationship can be used to estimate $K_{\mathrm{d}}$ for aquifer sands where sulfur content is low (e.g., $\mathrm{Fe} / \mathrm{S}>1$ ), sediment $\mathrm{Fe}(\mathrm{III}) / \mathrm{Fe}$ ratio is between $0.3-0.9$, and As mobility is governed by interaction with $\mathrm{Fe}$ minerals. The nearly constant $K_{\mathrm{d}}$ values of 2-6 reported for reducing GBMD aquifer sediments with $\mathrm{Fe}(\mathrm{III}) /$ $\mathrm{Fe}<0.5^{8,12,13}$ is thus not surprising.
Despite a number of limitations such as unavailable $\mathrm{Fe}$ mineralogy data for desorption experiment, spatially and seasonally heterogeneous sediment composition, and lack of differentiation between adsorption and coprecipitation, the results from this coupled field, experimental, and modeling study underscore the importance of characterizing the mineralogy, redox state, and surface site density of sediments of aquifers that are affected by seasonal and spatial redox transition. Recharge and discharge zones of the floodplain aquifer of South Asia, where seasonal and spatial redox transition is considerable due to groundwater-surface water interaction, ${ }^{18,20,22}$ are likely most susceptible to redox-dependent As partitioning through precipitation/dissolution and transformation of $\mathrm{Fe}$ minerals causing the change of the surface sorption site density. The sediment $\mathrm{Fe}(\mathrm{III}) / \mathrm{Fe}$ ratio is a useful parameter to assess the mobility and transport of groundwater As in iron-rich and sulfur-poor aquifers with circumneutral $\mathrm{pH}$, but will not apply in the iron-poor environment where sulfides dominate the mobility of As. ${ }^{11,34}$

\section{ASSOCIATED CONTENT}

\section{S Supporting Information}

Detailed sampling and analysis methods, chemical composition of water and sediment, database for surface complexation modeling, batch sorption and desorption data, sampling location map. This information is available free of charge via the Internet at http://pubs.acs.org.

\section{AUTHOR INFORMATION}

\section{Corresponding Author}

*Phone: 718-997-3300; fax: 718-997-3299; e-mail: yan.zheng@ qc.cuny.edu, yzheng@ldeo.columbia.edu.

\section{Present Address}

${ }^{\S}$ Pacific Northwest National Laboratory, Richland, WA 99354, USA.

\section{ACKNOWLEDGMENTS}

Funding was provided by NIEHS SBRP 2 P42 ES10349 to Y.Z. H.B.J. received a University Fellowship and Mina Rees Dissertation Fellowship from the Graduate Center, CUNY. We are grateful to Mohammad W. Rahman, Mohammad M. Rahman, and Mohammad Rezaul Huq for assistance in the field.

\section{REFERENCES}

(1) Raven, K. P.; Jain, A.; Loeppert, R. H. Arsenite and arsenate adsorption on ferrihydrite: Kinetics, equilibrium, and adsorption envelopes. Environ. Sci. Technol. 1998, 32, 344-349.

(2) Goldberg, S. Competitive adsorption of arsenate and arsenite on oxides and clay minerals. Soil Sci. Soc. Am. J. 2002, 66, 413-421.

(3) Manning, B. A.; Fendorf, S. E.; Bostick, B.; Suarez, D. L. Arsenic(III) oxidation and arsenic(V) adsorption reactions on synthetic birnessite. Environ. Sci. Technol. 2002, 36, 976-981.

(4) Dixit, S.; Hering, J. G. Comparison of arsenic(V) and arsenic(III) sorption onto iron oxide minerals: Implications for arsenic mobility. Environ. Sci. Technol. 2003, 37, 4182-4189.

(5) Manning, B. A.; Goldberg, S. Arsenic(III) and arsenic(V) adsorption on three California soils. Soil Sci. 1997, 162, 886-895.

(6) Smith, E.; Naidu, R.; Alston, A. M. Chemistry of arsenic in soils: I. Sorption of arsenate and arsenite by four Australian soils. J. Environ. Qual. 1999, 28, 1719-1726.

(7) Zhang, H.; Selim, H. M. Kinetics of arsenate adsorptiondesorption in soils. Environ. Sci. Technol. 2005, 39, 6101-6108. 
(8) BGS and DPHE. Arsenic Contamination of Groundwater in Bangladesh, Final Report; British Geological Survey Report WC/00/19; Kinniburgh, D. G., Smedley, P. L., Eds.; British Geological Survey: Keyworth, 2001.

(9) Jung, H. B.; Charette, M. A.; Zheng, Y. Field, Laboratory, and Modeling Study of Reactive Transport of Groundwater Arsenic in a Coastal Aquifer. Environ. Sci. Technol. 2009, 43, 5333-5338.

(10) Ford, R. G.; Wilkin, R. T.; Hernandez, G. Arsenic cycling within the water column of a small lake receiving contaminated ground-water discharge. Chem. Geol. 2006, 228, 137-155.

(11) O’Day, P. A.; Vlassopoulos, D.; Root, R. A.; Rivera, N. A. The influence of sulfur and iron on dissolved arsenic concentrations in the shallow subsurface under changing redox conditions. Proc. Natl. Acad. Sci. U. S. A. 2004, 101, 13703-13708.

(12) Harvey, C. F.; Swartz, C. H.; Badruzzaman, A. B. M.; KeonBlute, N.; Yu, W.; Ali, M. A.; Jay, J.; Beckie, R.; Niedan, V.; Brabander, D.; Oates, P. M.; Ashfaque, K. N.; Islam, S.; Hemond, H. F.; Ahmed, M. F. Arsenic mobility and groundwater extraction in Bangladesh. Science 2002, 298, 1602-1606.

(13) van Geen, A.; Zheng, Y.; Goodbred, S.; Horneman, A.; Aziz, Z.; Cheng, Z.; Stute, M.; Mailloux, B.; Weinman, B.; Hoque, M. A.; Seddique, A. A.; Hossain, M. S.; Chowdhury, S. H.; Ahmed, K. M. Flushing history as a hydrogeological control on the regional distribution of arsenic in shallow groundwater of the Bengal Basin. Environ. Sci. Technol. 2008, 42, 2283-2288.

(14) Stollenwerk, K. G.; Breit, G. N.; Welch, A. H.; Yount, J. C.; Whitney, J. W.; Foster, A. L.; Uddin, M. N.; Majumder, R. K.; Ahmed, $\mathrm{N}$. Arsenic attenuation by oxidized aquifer sediments in Bangladesh. Sci. Total Environ. 2007, 379, 133-150.

(15) Dhar, R. K.; Zheng, Y.; Saltikov, C. W.; Radloff, K. A.; Mailloux, B. J.; Ahmed, K. M.; van Geen, A. Microbes Enhance Mobility of Arsenic in Pleistocene Aquifer Sand from Bangladesh. Environ. Sci. Technol. 2011, 45, 2648-2654.

(16) Radloff, K. A.; Zheng, Y.; Michael, H. A.; Stute, M.; Bostick, B. C.; Mihajlov, I.; Bounds, M.; Huq, M. R.; Choudhury, I.; Rahman, M. W.; Schlosser, P.; Ahmed, K. M.; van Geen, A. Arsenic migration to deep groundwater in Bangladesh influenced by adsorption and water demand. Nat. Geosci. 2011, 4, 793-798.

(17) Neumann, R. B.; Ashfaque, K. N.; Badruzzaman, A. B. M.; Ali, M. A.; Shoemaker, J. K.; Harvey, C. F. Anthropogenic influences on groundwater arsenic concentrations in Bangladesh. Nat. Geosci. 2010, 3, 46-52.

(18) Datta, S.; Mailloux, B.; Jung, H. B.; Hoque, M. A.; Stute, M.; Ahmed, K. M.; Zheng, Y. Redox trapping of arsenic during groundwater discharge in sediments from the Meghna riverbank in Bangladesh. Proc. Natl. Acad. Sci. U. S. A. 2009, 106, 16930-16935.

(19) Fendorf, S.; Michael, H. A.; van Geen, A. Spatial and Temporal Variations of Groundwater Arsenic in South and Southeast Asia. Science 2010, 328, 1123-1127.

(20) Polizzotto, M. L.; Harvey, C. F.; Sutton, S. R.; Fendorf, S. Processes conducive to the release and transport of arsenic into aquifers of Bangladesh. Proc. Natl. Acad. Sci. U. S. A. 2005, 102, 18819-18823.

(21) Postma, D.; Larsen, F.; Minh Hue, N. T.; Duc, M. T.; Viet, P. H.; Nhan, P. Q.; Jessen, S. Arsenic in groundwater of the Red River floodplain, Vietnam: Controlling geochemical processes and reactive transport modeling. Geochim. Cosmochim. Acta 2007, 71, 5054-5071.

(22) Polizzotto, M. L.; Kocar, B. D.; Benner, S. G.; Sampson, M.; Fendorf, S. Near-surface wetland sediments as a source of arsenic release to ground water in Asia. Nature 2008, 454, 505-508.

(23) O'Day, P. A.; Rivera, N.; Root, R.; Carroll, S. A. X-ray absorption spectroscopic study of $\mathrm{Fe}$ reference compounds for the analysis of natural sediments. Am. Mineral. 2004, 89, 572-585.

(24) Dzombak, D. A.; Morel, F. M. M. Surface Complexation Modeling: Hydrous Ferric Oxide; Wiley-Interscience: New York, 1990.

(25) Mathur, S. S.; Dzombak, D. A. Surface complexation modeling: goethite. In Surface Complexation Modeling; Lutzenkirchen, J., Ed.; Elsevier: Amsterdam, 2006.
(26) Appelo, C. A. J.; Postma, D. Geochemistry, Groundwater and Pollution; A.A. Balkema Publishers: Leiden Netherlands, 2005.

(27) Zachara, J. M.; Kukkadapu, R. K.; Fredrickson, J. K.; Gorby, Y. A.; Smith, S. C. Biomineralization of poorly crystalline Fe(III) oxides by dissimilatory metal reducing bacteria (DMRB). Geomicrobiol. J. 2002, 19, 179-207.

(28) Hansel, C. M.; Benner, S. G.; Neiss, J.; Dohnalkova, A.; Kukkadapu, R. K.; Fendorf, S. Secondary mineralization pathways induced by dissimilatory iron reduction of ferrihydrite under advective flow. Geochim. Cosmochim. Acta 2003, 67, 2977-2992.

(29) Cornell, R. M.; Schwertmann, U. The Fe Oxides: Structure, Properties, Reactions, Occurrences, and Uses; VCH Weinheim: Federal Republic of Germany, 1996.

(30) Sverjensky, D. A.; Fukushi, K. A predictive model (ETLM) for As(III) adsorption and surface speciation on oxides consistent with spectroscopic data. Geochim. Cosmochim. Acta 2006, 70, 3778-3802.

(31) Berg, M.; Luzi, S.; Trang, P. T. K.; Viet, P. H.; Giger, W.; Stuben, D. Arsenic Removal from Groundwater by Household Sand Filters: Comparative Field study, Model Calculations, and Health Benefits. Environ. Sci. Technol. 2006, 40, 5567-5573.

(32) Islam, F. S.; Gault, A. G.; Boothman, C.; Polya, D. A.; Charnock, J. M.; Chatterjee, D.; Lloyd, J. R. Role of metal-reducing bacteria in arsenic release from Bengal delta sediments. Nature 2004, 430, 68-71.

(33) Horneman, A.; van Geen, A.; Kent, D. V.; Mathe, P. E.; Zheng, Y.; Dhar, R. K.; O’Connell, S. O.; Hoque, M. A.; Aziz, A.; Shamsuddhua, M.; Seddique, A. A.; Ahmed, K. M. Decoupling of As and $\mathrm{Fe}$ release to Bangladesh groundwater under reducing conditions. Part I: Evidence from sediment profiles. Geochim. Cosmochim. Acta 2004, 68, 3459-3473.

(34) Keimowitz, A. R.; Zheng, Y.; Chillrud, S. N.; Mailloux, B.; Jung, H. B.; Stute, M.; Simpson, H. J. Arsenic Redistribution between Sediments and Water near a Highly Contaminated Source. Environ. Sci. Technol. 2005, 39, 8606-8613. 